\title{
First record of a Late Holocene fauna associated with an ephemeral fluvial sequence in La Pampa Province, Argentina. Taphonomy and paleoenvironment
}

\author{
Claudia I. Montalvo ${ }^{\text {a, * }}$, Fernando J. Fernández ${ }^{\text {b }}$, M. Susana Bargo ${ }^{c}$, Rodrigo L. Tomassini ${ }^{\text {d }}$, \\ Adriana Mehl a, e \\ ${ }^{a}$ Facultad de Ciencias Exactas y Naturales, Universidad Nacional de La Pampa, Av. Uruguay 151, 6300 Santa Rosa, La Pampa, Argentina \\ b CONICET. Cátedra de Anatomía Comparada, Facultad de Ciencias Naturales y Museo, Universidad Nacional de La Plata, Calle $64 \mathrm{~s} / \mathrm{n}$ (entre diag. 113 y Calle \\ 120), 1900 La Plata, Buenos Aires, Argentina \\ c CIC. División Paleontología Vertebrados, Museo de La Plata, Unidades de Investigación, Anexo Museo, 60 y 122, 1900 La Plata, Argentina \\ d CONICET-INGEOSUR, Departamento de Geología Universidad Nacional del Sur, San Juan 670, 8000, Bahía Blanca, Buenos Aires, Argentina \\ e Instituto de Ciencias de la Tierra y Ambientales de La Pampa (CONICET-Universidad Nacional de La Pampa), Av. Uruguay 151, 6300, Santa Rosa, La Pampa, \\ Argentina
}

\section{A R T I C L E I N F O}

\section{Article history:}

Received 2 February 2017

Received in revised form

17 March 2017

Accepted 17 March 2017

Available online 21 March 2017

\section{Keywords:}

Taphonomy

Stratigraphy

Mammals

Holocene

Pampean region

South America

\begin{abstract}
A B S T R A C T
The first Late Holocene mammal assemblage (mainly micromammals) of La Pampa Province was found in Quehué paleontological site, associated with an ephemeral fluvial sequence. Taphonomical features of the collected materials were evaluated in order to increase the knowledge of the ancient vertebrate communities of this area and to interpret the origin of the assemblages. Field data and taphonomic analysis of the specimens, suggested the recognition of three assemblages with different taphonomic histories: 1) large to medium sized mammals; 2) micromammals found inside burrows or associated with them; and 3) discrete accumulations of micromammals and other microvertebrates (amphibians, reptiles and birds). Additionally, the paleoenvironmental analysis based mainly on the record of small mammals reflected the predominance of semi-arid conditions associated with a mosaic of open shrub steppe, grasslands and xerophytic forests of Espinal, similar to the present one in the Quehué valley area. However, the presence of Lestodelphys halli in the Quehué site during the Late Holocene ( 1.2 ky BP), suggests a more heterogeneous environment and perhaps relative colder and drier than current times, which are featured by more mesic conditions and anthropic activities, mainly agriculture and livestock during the last centuries.
\end{abstract}

() 2017 Elsevier Ltd. All rights reserved.

\section{Introduction}

Quaternary vertebrate faunas from central Argentina are among the richest and most diverse of South America. It is well-known that the Pampean Region of Argentina has provided the basis for the chronobiostratigraphic continental scheme of South America (Cione and Tonni, 2005; Cione et al., 2015). The record of small mammals recovered in the last decades largely increased the knowledge of the communities inhabiting the area during this interval. However, detailed taphonomic studies that supply information for the understanding of the origin of the assemblages are

\footnotetext{
* Corresponding author.

E-mail address: cmontalvo@exactas.unlpam.edu.ar (C.I. Montalvo).
}

still scarce (e.g. Pardiñas, 1999, 2001, 2004; Cenizo and De los Reyes, 2008; Montalvo et al., 2012; Quintana, 2015; Tomassini et al., 2017). It is worth highlighting that there are no studies of Late Holocene fauna records toward the western Pampean Region (i.e. La Pampa Province). In addition, paleoenvironmental studies in La Pampa Province are scarce, including a sedimentological and palynological analysis of Salina Anzoátegui in the south-east (Schäbitz, 1994) and a sedimentological analysis of Quehué valley in the central-east (Mehl, 2011; see below).

The fauna analyzed in this contribution comes from the middle levels of a Late Holocene sedimentary sequence that crops out at Quehué paleontological site. This is the first Late Holocene record for La Pampa Province. The aim of this paper is to analyze the taphonomic features of the materials recovered from the fluvial 
deposits of this site to interpret the origin of the assemblages. The taphonomic study provides new information on the preservation of skeletal remains in different contexts within fluvial environment and serves as a frame of reference for the analysis of similar assemblages recovered from Holocene paleontological and archaeological sites. In addition, on the basis of the record of small mammals, a paleoenvironmental analysis is presented.

\section{Geographic and stratigraphic setting}

The Quehué paleontological site is located in the Quehué valley $\left(\sim 37^{\circ} \mathrm{S}, 65^{\circ} \mathrm{W}\right.$, La Pampa Province; Fig. 1a), in the western part of the Pampean Region known as Dry Pampas. The climate of the Pampean Region is determined by the Atlantic anticyclone, which reduces its effects regionally from northeast to southwest. This results in a heterogeneous climate, which changes gradually from humid in the northeastern area (mean annual precipitation of $1200 \mathrm{~mm}$; mean annual temperature of $18^{\circ} \mathrm{C}$ ) to dry sub-humid in the southwestern area (mean annual precipitation of $600 \mathrm{~mm}$; mean annual temperature of $14^{\circ} \mathrm{C}$; Burgos, 1968). Quehué valley is included in the Espinal Phytogeographic Province (Fig. 1a), dominated by xerophytic forest (Prosopis caldenia), but also having grasslands (Stipa spp.), creosote bushes (Larrea spp.) scrublands (Condalia microphylla and Prosopis flexuosa), and deforested agricultural land and pastures (Cabrera, 1976). This area is characterized by the presence of strigiform birds such as Tyto alba (barn owl), Athene cunicularia (burrowing owl), Bubo virginianus (great horned owl) and Asio flammeus (short-eared owl). It also includes several mammal species such as the white-eared opossum (Didelphys albiventris), cougars (Puma concolor), wild cats (Leopardus spp. and Puma yagouaroundi), armadillos (Chaetophractus spp.), foxes (Lycalopex gymnocercus), grisons (Galictis cuja), skunks (Conepatus chinga) and numerous rodents.

The Late Quaternary alluvial sequence of the Quehué valley crops out with a lateral continuity of several hundred meters and a 3-m-average thickness forming a terrace along the banks of the Quehué ephemeral creek, that drains approximately $30 \mathrm{~km}$ of the valley (from $\sim 37^{\circ} 06^{\prime} 42^{\prime \prime} \mathrm{S}-64^{\circ} 52^{\prime} 27^{\prime \prime} \mathrm{W}$ to $3^{\circ} 01^{\prime} 16^{\prime \prime} \mathrm{S}-64^{\circ} 31^{\prime}$ $46^{\prime \prime} \mathrm{W}$; Fig. 1b). The present-day talweg of the stream is located at the stratigraphic contact between Late Quaternary and Late Miocene (Cerro Azul Formation) deposits (Fig. 1e); the last one, also forming the structural plain in which the Quehué valley has been carved.

In the area of the Quehué paleontological site, where fossil specimens were found, the lower section of the Late Quaternary sequence, named Unit 1 in this contribution (Lithofacies 1 in Mehl and Zárate, 2008, Fig. 1c; d), exhibits horizontally laminated clayey silts and an incipient spongy pedological structure -paleosol- on its top most part. Some megamammals, i.e. Toxodontidae indet. (Notoungulata) and Neosclerocalyptus sp. (Xenarthra, Glyptodontidae), were recovered from the base of this sequence (Montalvo et al., 2007; Bargo et al., 2010). Recently, two mandible fragments assigned to Hippidion sp. (Equidae, Perissodactyla) were also recovered in this level. The sedimentary organic matter content on the topmost part of the paleosol was dated and yielded an age of $9040 \pm 580{ }^{14} \mathrm{C}$ years BP, indicating a minimum age for the soil -close to the end of soil forming processes due to the burial- (Mehl and Zárate, 2008).

Unit 1 is covered by massive silty very fine sands with common calcium carbonate clasts, corresponding to the Unit 2 (Lithofacies 3 in Mehl and Zárate, 2008, Fig. 1e); it shows an undulate and abrupt lower limit with sandy-clayey silts clasts cemented by calcium carbonate, indicating a likely drier and warm atmosphere (Mehl, 2011). Laminated and/or massive infilled burrows with a tunnel average diameter of $8 \mathrm{~cm}$ were recorded in this level (Fig. 1f).
Vertebrate specimens recovered from Unit 2 are evaluated in this paper (Fig. $1 \mathrm{~g}$ and $\mathrm{h}$ ). The topmost part of this unit is slightly harder and has faint red oxidation color (poorly developed soil). The sedimentary organic matter content was dated and yielded an age of $1258 \pm 75{ }^{14} \mathrm{C}$ years BP (Mehl and Zárate, 2008).

Units 1 and 2 were aggraded from water flows transporting silt and fine sand as suspended load (Mehl and Zárate, 2008). The generation of sedimentary aggradation processes in a fluvial environment of ephemeral characteristics suggests seasonal or sporadic water availability in the fluvial valley (Mehl, 2011). The development of pedogenetic processes in the topmost part of the silty sand deposits of Unit 2 would indicate a new period of better conditions and stability, possibly associated with regional reconstructions of the climatic event of the Medieval Climatic Anomaly (MCA) (Mehl, 2011).

The basal part of Unit 2 exhibits a lateral change to a paludal deposit of limited areal distribution, defined here as Unit 2a (Lithofacies 2 in Mehl and Zárate, 2008, Fig. 1d). An age of $8083 \pm 73{ }^{14} \mathrm{C}$ years BP was obtained based on sedimentary organic matter content (Mehl and Zárate, 2008). It indicates deposition in a temporary waterlogged environment in some moment during the Early Holocene. The deposit of Unit $2 \mathrm{a}$ is cover by sediments of the upper part of Unit 2.

The predominantly fluvial sequence of Unit 1,2 and 2a was buried by a silty very fine sand cover of eolian genesis according to regional evidences (Lithofacies 4 in Mehl and Zárate, 2008, Fig. 1d). Likely this eolian aggradation process, could be related to the climatic conditions of the Little Ice Age (LIA) (Mehl, 2011).

\section{Materials and methods}

Vertebrate specimens were recovered from Unit 2 which is the fossiliferous unit and objective of this paper. Field observations suggested the existence of assemblages with different taphonomic histories preserved in a single deposit; thus, sampling, collection of materials, and taphonomic evaluation were made considering this context. The specimens are housed in the collection of the Facultad de Ciencias Exactas y Naturales, Universidad Nacional de La Pampa (acronym GHUNLPam), La Pampa Province, Argentina.

Mammals were classified as small (micromammals, $<1 \mathrm{~kg}$ ), medium (1-44 kg) and large ( $>45 \mathrm{~kg}$ ) according to the categories proposed by Martin and Steadman (1999), commonly used in archaeology and paleontology. Taphonomic features were analyzed with a Leica MS 5 binocular light microscope. Some specimens were photographed using a JEOL 35 CF SEM scanning electron microscope, belonging to the Unidad de Administración Territorial del Centro Científico y Tecnológico CONICET, Bahía Blanca (CCTCONICET-BB).

Frequency and diversity of taxa in each assemblage were estimated with the following indexes. NISP (number of identified specimens per taxon), MNI (minimum number of individuals) and MNE (minimum number of elements), according to Badgley (1986). MNI was calculated on the basis of the most abundant element per taxon, except for Dasypodidae. In this latter case, a MNI = 1 was considered for each of the identified species, because of the large amount of osteoderms present in the carapace and the high degree of disarticulation and dispersion of these elements (Montalvo, 2004). In the micromammal assemblage recovered inside burrows or associated with them, each association of specimens recorded was considered as $\mathrm{MNI}=1$.

The index isolated teeth/isolated vertebrae (Behrensmeyer, 1975; Behrensmeyer and Dechant Boaz, 1980), provides a criterion for determining if a group of bones was selectively biased before burial, and can be considered as an indicator of the degree of hydrodynamic sorting. The groups proposed by Voorhies (1969), 

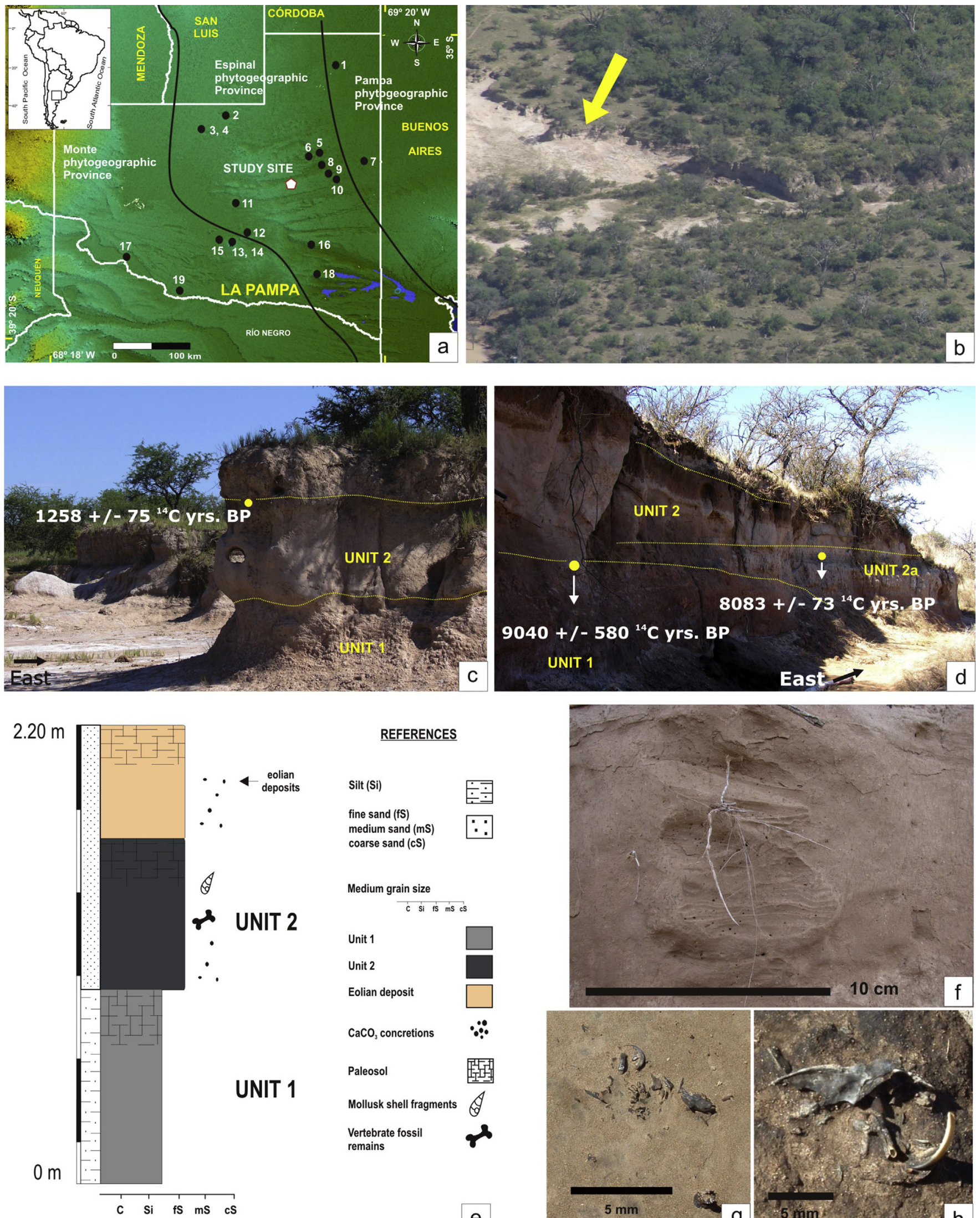

\section{REFERENCES}

Silt (Si)

fine sand (fS)

medium sand ( $\mathrm{mS}$ )

$\div \div$ coarse sand (CS)

Medium grain size c sil is ms os

UNIT 2

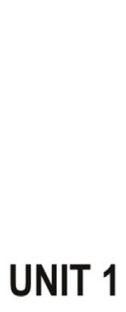

\section{Unit 1 \\ Unit 2}

Eolian deposit

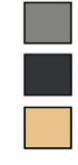

$\mathrm{CaCO}_{3}$ concretions

Paleosol

Mollusk shell fragments

Vertebrate fossil remains
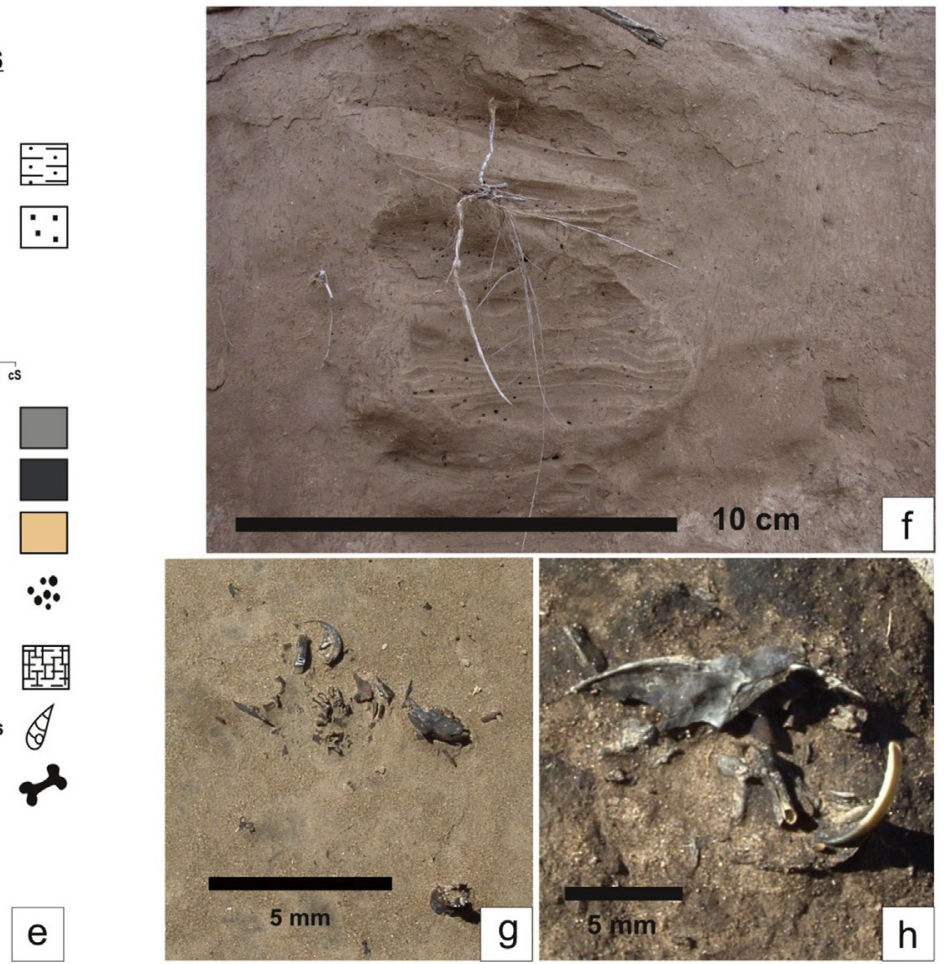

Fig. 1. a. Location map showing phytogeographic provinces, Quehué paleontological site and recent owl pellet samples: 1. Alta Italia; 2. Estancia La Elenita; 3, 4. Curru-Mahuida; 5 . Vivero Forestal Provincial; 6. Laguna Don Tomás; 7. Colonia San Miguel; 8. Bajo Giuliani; 9. Cantera Santa Rosa; 10. Reserva Parque Luro; 11. Estancia Arco Iris; 12. Estancia Los Ranqueles; 13, 14. Parque Nacional Lihué Calel; 15. Estancia La Manuela; 16. Estancia Luan Cura Hué; 17. Casa de Piedra; 18. Cuchillo Có; 19. Gobernador Duval. b. Panoramic view of the Quehué valley at the study area (see arrow). c. View of the outcrops near the study area showing units 1,2 and 4, and chronology of the section. d. View of outcrops, near the study area, showing units 1-4, and chronology of the section. e. Stratigraphic column of Quaternary units at the study area, showing the bearing level. f. Cross section of burrow in Unit 2. g, h. Discrete accumulations of micromammals in Unit 2. 
according to the susceptibility of the different skeletal elements to be mobilized by water, allow evaluating the hydrodynamic sorting. These two methodologies were calculated in the large to medium sized mammal assemblage.

\subsection{The following taphonomic attributes were analyzed}

- Articulation degree, according to the classification proposed by Behrensmeyer (1991): articulated, disarticulated but associated, and disarticulated and isolated.

- Breakage degree, weather the specimens (cranial and postcranial element were complete or incomplete. The type of fractures (smooth transverse, spiral and stepped; sensu Marshall, 1989) was analyzed in the incomplete specimens.

- Weathering degree, the following categories were considered for micromammals (modified from Andrews, 1990); 0: unweathered specimens (without alteration); 1: specimens showing surface slight splitting, parallel to the fibrous structure; 2: specimens showing more intense splitting, but little exfoliation. For medium to large mammals, the categories proposed by Alcalá (1994) were considered; 1: intact specimens; 2: specimens showing surface loss of bone material; and 3: specimens showing deep loss of bone material.

- Abrasion degree, following the categories proposed by Alcalá (1994); 1: intact specimens; 2: rounded specimens; and 3: polished specimens.

- Impregnation degree, considers the presence or absence of color changes due to the precipitation of manganese oxides. Different types of pigmentation caused by oxides impregnations have been distinguished following the classification proposed by Marín Arroyo et al. (2008); Type 0: typical light coloration; Type 1: light surface and small, dark brown, circular and internal stains; Type 2: uniformly light brown tone and glossy appearance; Type 3: uniformly dark brown tone and matt appearance; Type 4: uniformly black with occasional irregular bluish stains superimposed on the black pigmentation.

- Presence or absence of tooth marks and other bioerosive marks.

In order to determine whether the micromammal assemblage was accumulated by predators, specimens were evaluated according to the taphonomic methodology proposed by Andrews (1990) and Fernández-Jalvo and Andrews (1992), which includes the following indexes and analyses:

- Assessment of the relative abundance of skeletal elements considering the representation of each element in the context of the $\mathrm{MNI}=\mathrm{MNEi} /(\mathrm{Ei} \times \mathrm{MNI}) \times 100$, where MNEi is the minimum number of a given skeletal element in the sample, and $\mathrm{Ei}$ is the expected number of that skeletal element in an individual.

- Calculation of indexes of proportion of elements: relation between cranial and postcranial elements (femora + humeri)/ $($ mandibles + maxillae $)=\mathrm{f}+\mathrm{h} / \mathrm{md}+\mathrm{mx}$, and relation between proximal and distal limb elements (tibiae + ulnae)/ (femora + humeri $)=\mathrm{t}+\mathrm{u} / \mathrm{f}+\mathrm{h}$.

- Evaluation of the postcranial breakage degree (femora, humeri, radii, tibiae and ulnae; complete or proximal and distal portions), comparing the number of complete specimens against the number of proximal, shaft, and distal portions.

- Analysis of the degree of digestive corrosion, performed mainly on teeth, proximal portions of femora, and distal portions of humeri. Differences among modifications by digestion in teeth of the rodents Cricetidae, Ctenomyidae and Caviidae were evaluated according to the methodology proposed by Fernández et al. (2017).

Small mammals have been widely used as indicators of paleoenvironmental conditions since they are abundant and diverse in the archaeological and paleontological records. Most taxa have relatively narrow environmental requirements, being frequently associated with particular microenvironments. Paleoecological inferences are usually based on presence/absence of some species and/or relative changes of their frequencies (e.g. Andrews, 1990; Pardiñas, 1999).

Taking into account that taphonomic and taxonomic evidences suggest strigiform birds as the main producers of the discrete accumulations of microvertebrates (see Discussion), paleoenvironmental reconstruction was based on comparisons between both fossil and living small mammal assemblages derivate from pellets samples produced by Tyto alba and Athene cunicularia that were recovered from nest and roosting sites at precise localities of Monte, Espinal and Pampa biomes (La Pampa Province) (Table 1, Fig. 1a). Correspondence analysis was performed in order to explore species and samples ordination in multivariate space selecting those fossil and current small mammal samples with $\mathrm{MNI} \geq 50$, after

\section{Table 1}

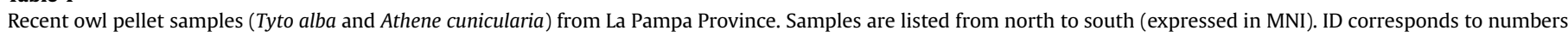

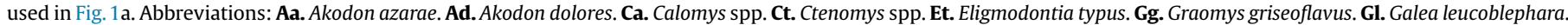

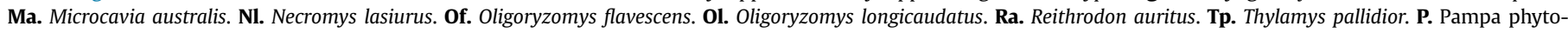
geographic Province. E. Espinal phytogeographic Province. M. Monte phytogeographic Province.

\begin{tabular}{|c|c|c|c|c|c|c|c|c|c|c|c|c|c|c|c|c|c|}
\hline ID & Localities & $\mathrm{Aa}$ & Ad & $\mathrm{Ca}$ & $\mathrm{Ct}$ & Et & Gg & Gl & Ma & $\mathrm{Nl}$ & Of & Ol & $\mathrm{Ra}$ & Tp & Total & Owl & References \\
\hline 1 & Alta Italia $(\mathrm{P})$ & 4 & 4 & 296 & 0 & 0 & 0 & 0 & 0 & 0 & 3 & 0 & 2 & 0 & 305 & Tyto & Massoia and Vetrano (1988) \\
\hline 2 & Estancia La Elenita (E) & 11 & 3 & 131 & 0 & 0 & 19 & 0 & 0 & 0 & 0 & 0 & 1 & 0 & 154 & Tyto & Tiranti (1988) \\
\hline 3 & Curru-Mahuida (E) & 0 & 1 & 10 & 72 & 3 & 0 & 1 & 0 & 0 & 0 & 0 & 0 & 11 & 98 & Athene & Solaro et al. (2012) \\
\hline 4 & Curru-Mahuida (E) & 31 & 68 & 158 & 18 & 17 & 5 & 0 & 0 & 4 & 1 & 0 & 0 & 14 & 285 & Tyto & Solaro et al. (2012) \\
\hline 5 & Vivero Forestal Provincial (E) & 10 & 1 & 52 & 1 & 0 & 2 & 0 & 0 & 0 & 2 & 0 & 3 & 0 & 61 & Tyto & Tiranti (1988) \\
\hline 6 & Laguna Don Tomás (E) & 1 & 0 & 1 & 3 & 0 & 0 & 0 & 0 & 0 & 0 & 0 & 0 & 0 & 4 & Athene & Montalvo and Tejerina (2009) \\
\hline 7 & Colonia San Miguel (P) & 0 & 0 & 54 & 0 & 0 & 0 & 0 & 0 & 0 & 0 & 0 & 0 & 0 & 54 & Tyto & Tiranti (1988) \\
\hline 8 & Bajo Giuliani (E) & 12 & 11 & 114 & 1 & 69 & 5 & 0 & 1 & 0 & 6 & 0 & 47 & 4 & 258 & Tyto & De Santis et al. (1983) \\
\hline 9 & Cantera Santa Rosa (E) & 5 & 1 & 47 & 3 & 212 & 6 & 0 & 0 & 0 & 5 & 0 & 11 & 0 & 285 & Tyto & Tiranti (1994) \\
\hline 10 & Reserva Parque Luro (E) & 11 & 71 & 155 & 1 & 78 & 20 & 1 & 0 & 0 & 6 & 0 & 6 & 7 & 345 & Tyto & Tiranti (1994) \\
\hline 11 & Estancia Arco Iris (E) & 1 & 2 & 9 & 0 & 7 & 0 & 0 & 0 & 0 & 0 & 0 & 1 & 3 & 22 & Tyto & Tiranti (1988) \\
\hline 12 & Estancia Los Ranqueles (E) & 7 & 45 & 47 & 7 & 53 & 34 & 1 & 0 & 0 & 2 & 3 & 4 & 10 & 206 & Tyto & Tiranti (1988) \\
\hline 13 & Parque Nacional Lihué Calel (M) & 5 & 149 & 46 & 56 & 17 & 34 & 1 & 3 & 0 & 0 & 8 & 8 & 14 & 336 & Tyto & Fracassi et al. (2004) \\
\hline 14 & Parque Nacional Lihué Calel (M) & 0 & 1 & 19 & 56 & 17 & 3 & 0 & 1 & 0 & 0 & 0 & 8 & 4 & 109 & Athene & Tommaso et al. (2009) \\
\hline 15 & Estancia La Manuela (M) & 0 & 5 & 4 & 38 & 35 & 23 & 1 & 1 & 0 & 0 & 0 & 2 & 8 & 117 & Athene & Tommaso et al. (2009) \\
\hline 16 & Estancia Luan Cura Hué (E) & 99 & 47 & 93 & 23 & 76 & 11 & 1 & 0 & 0 & 18 & 0 & 11 & 47 & 327 & Tyto & Tiranti (1992) \\
\hline 17 & Casa de Piedra (M) & 0 & 72 & 0 & 11 & 130 & 58 & 7 & 5 & 0 & 0 & 0 & 1 & 16 & 300 & Tyto & Montalvo et al. (1985) \\
\hline 18 & Cuchillo Có (E) & 5 & 6 & 134 & 0 & 66 & 26 & 0 & 0 & 0 & 0 & 0 & 8 & 10 & 250 & Tyto & Tiranti (1992) \\
\hline 19 & Gobernador Duval (M) & 0 & 2 & 2 & 2 & 17 & 1 & 0 & 0 & 0 & 0 & 0 & 1 & 4 & 29 & Tyto & Tiranti (1988) \\
\hline
\end{tabular}


exploration of sample-size effects on their taxonomical structures. This evaluation was made on a data matrix of relative abundances (\%MNI). Statistical analysis was made using the program PAST (PAleontological STatistics), version 3.12.

\section{Results}

The Late Holocene specimens studied herein $(\mathrm{NISP}=1099)$ come from the middle portion of the sedimentary sequence (Unit 2 ). Specimens of amphibians, reptiles and birds, not included in the taphonomic analysis, were also recovered from the same level. The field taphonomic evaluation of these specimens and their disposition in the sedimentary sequence allowed distinguishing three assemblages: 1) large to medium sized mammals; 2) small mammals (micromammals) recovered inside burrows or associated with them; and 3) discrete accumulations of micromammals and other microvertebrates.

\subsection{Large to medium sized mammals}

\subsubsection{Taxonomic structure}

This assemblage is composed by xenarthrans, artiodactyls, carnivores and rodents. Xenarthrans are represented mostly by osteoderms that belong to different species of Dasypodidae (Table 2, Fig. 2a-c), and three fragments of mandibles assigned to Dasypodidae indet. The remaining taxa include by Canidae, Camelidae, Chinchillidae and Caviidae (Table 2, Fig. 2d-g).

The assemblage is characterized by a MNI of 11 (Table 2). Without considering Dasypodidae osteoderms, NISP is 75 and MNE is 64. NISP and MNE of Dasypodidae osteoderms is 106, including 49 isolated osteoderms, and four sets of 10,10,15 and 22 associated osteoderms each one.

\subsubsection{Taphonomic signature}

The $33 \%$ of the specimens correspond to cranial elements (maxillae, mandibles and isolated teeth), while the remaining percentage includes diverse postcranial elements. The anatomical representation indicates that vertebrae (31\%), metapodials $(14 \%)$ and mandibles (12\%) are the most frequent elements; other elements present very low percentages or are absent (Fig. 3). The index isolated teeth/isolated vertebrae is 1.5. All the skeletal elements belonging to the groups proposed by Voorhies (1969) are represented. Disarticulated and isolated specimens (sensu Behrensmeyer, 1991) are dominant (79\%); while the rest, including osteoderms of the different species of Dasypodidae and vertebrae of small indeterminate mammals, are disarticulated but associated (sensu Behrensmeyer, 1991). Incomplete specimens represent $22.66 \%$ of the sample; $60 \%$ of them presents smooth transverse fractures, $23 \%$ stepped fractures and $17 \%$ spiral fractures. Complete specimens (77.44\%) include isolated molars, osteoderms, vertebrae, metapodials and femora. One palate with both P4-M3 series assigned to Lama sp., presents its right portion (including the dental series) collapsed and displaced backward, resulting in the breakage of this area of the palate (Fig. 2e). None of these specimens show signs of digestions. Tooth marks are absent.

Only $2.80 \%$ of the specimens shows surface loss of bone material related with weathering, represented by slight splitting parallel to the fibrous structure (category 2, sensu Alcalá, 1994). There are no specimens with abrasion evidence (category 1, sensu Alcalá, 1994). Impregnation with manganese oxides is present in all the specimens, most of them (80\%) assigned to Type 1 (sensu Marín Arroyo et al., 2008), while the remaining can be included in Type 4 (sensu Marín Arroyo et al., 2008).

\subsection{Micromammals associated with burrows}

\subsubsection{Taxonomic structure}

Specimens of this assemblage were recovered inside the burrows or associated with them (Fig. 1f). The assemblage is composed exclusively by rodents, including the caviomorphs Ctenomys sp. (88\%) and Galea leucoblephara (4\%), and the cricetid Reithrodon auritus (8\%) (Table 2). Specimens of Ctenomys are fragmentary, being very difficult their identification at species level. Ctenomys azarae, C. talarum and possibly also C. mendocinus are currently present in the area of the Quehué valley (Bidau, 2015). The NISP of the assemblage is 160 , the MNE is 144 and the MNI is 25 (Table 2). Only one individual was considered from each burrow.

\subsubsection{Taphonomic signature}

The $55.63 \%$ of the specimens correspond to cranial elements (maxillae, mandibles and isolated teeth), while the remaining percentage includes diverse postcranial elements. There is a high frequency of mandibles, maxillae, isolated teeth and vertebrae (mainly of Ctenomys sp., the best represented taxon) (Fig. 4). The

Table 2

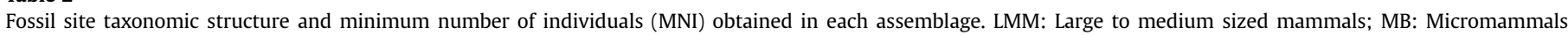
associated with burrows; MA: Micromammals accumulations.

\begin{tabular}{|c|c|c|c|c|c|}
\hline \multirow[t]{2}{*}{ Order } & \multirow[t]{2}{*}{ Family } & \multirow[t]{2}{*}{ Taxon } & \multicolumn{3}{|c|}{ Assemblages } \\
\hline & & & LMM & MB & MA \\
\hline \multirow[t]{3}{*}{ Xenarthra } & Dasypodidae & Chaetophractus villosus & 1 & & \\
\hline & & Chaetophractus cf. C. vellerosus & 1 & & \\
\hline & & Zaedyus pichiy & 1 & & \\
\hline Artiodactyla & Camelidae & Lama sp. & 2 & & \\
\hline Carnivora & Canidae & Lycalopex gymnocercus & 1 & & \\
\hline \multirow[t]{10}{*}{ Rodentia } & Chinchillidae & Lagostomus sp. & 4 & & \\
\hline & Caviidae & Dolichotis sp. & 1 & & \\
\hline & & Microcavia australis & & & 9 \\
\hline & & Galea leucoblephara & & 1 & 2 \\
\hline & Ctenomyidae & Ctenomys sp. & & 22 & 59 \\
\hline & Cricetidae & Reithrodon auritus & & 2 & 15 \\
\hline & & Calomys cf. C. laucha-C. musculinus & & & 1 \\
\hline & & Graomys griseoflavus & & & 4 \\
\hline & & Akodon dolores & & & 2 \\
\hline & & Eligmodontia typus & & & 2 \\
\hline \multirow[t]{3}{*}{ Didelphimorphia } & Didelphidae & Thylamys pallidior & & & 2 \\
\hline & & Lestodelphys halli & & & 2 \\
\hline & & Total MNI & 12 & 25 & 99 \\
\hline
\end{tabular}



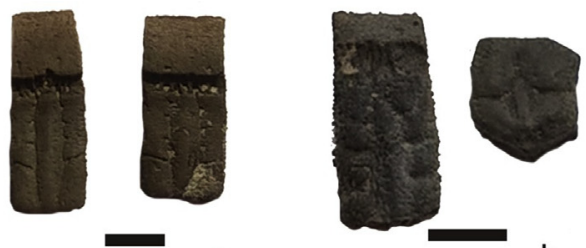

a
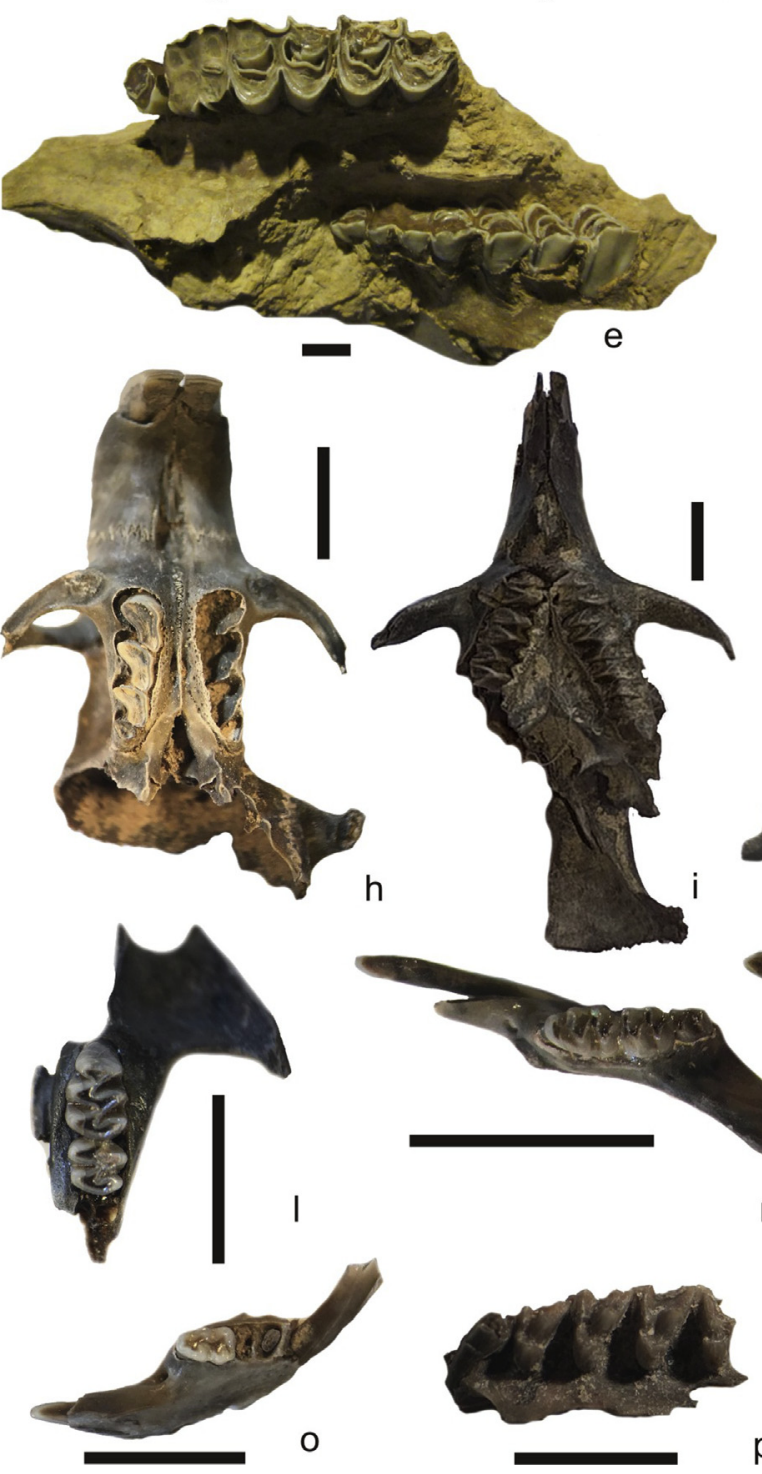

m

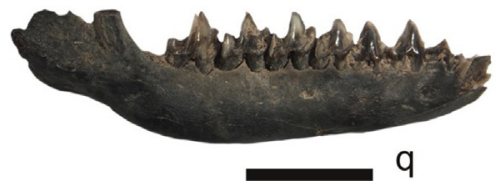

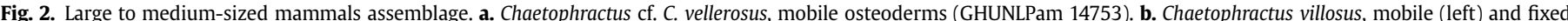

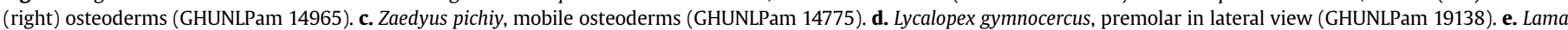

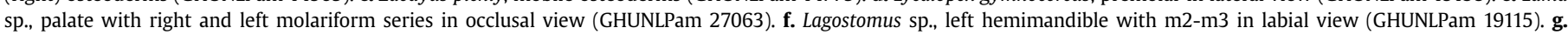

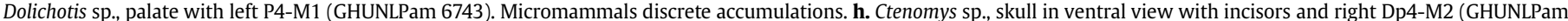

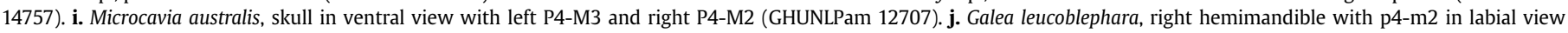

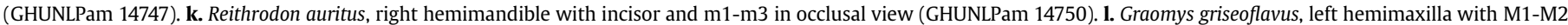

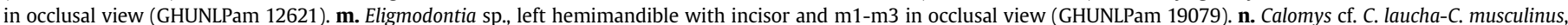

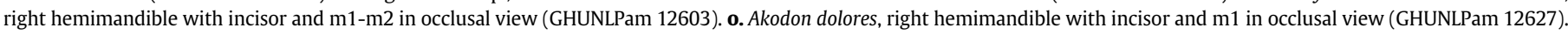

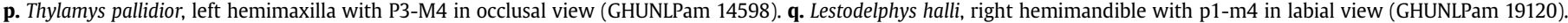
Scales $=5 \mathrm{~mm}$.

other elements are absent or in very low values (Fig. 4).

The average of the relative abundance is $13.02 \%$. The relationship between cranial and postcranial elements (20.31) shows a deficit of postcranial bones, and relationship between proximal and distal elements of the limbs (38.46) reflects loss of distal bones.

The specimens of all individuals are disarticulated but associated (sensu Behrensmeyer, 1991). The 90\% of the specimens are incomplete; $50 \%$ of them present smooth transverse fractures, $32 \%$ stepped fractures and $18 \%$ spiral fractures. Complete specimens only include vertebrae and hemimandibles.

None of the specimens shows signs of weathering (category 0 ), abrasion (category 1, sensu Alcalá, 1994) tooth marks and digestive 


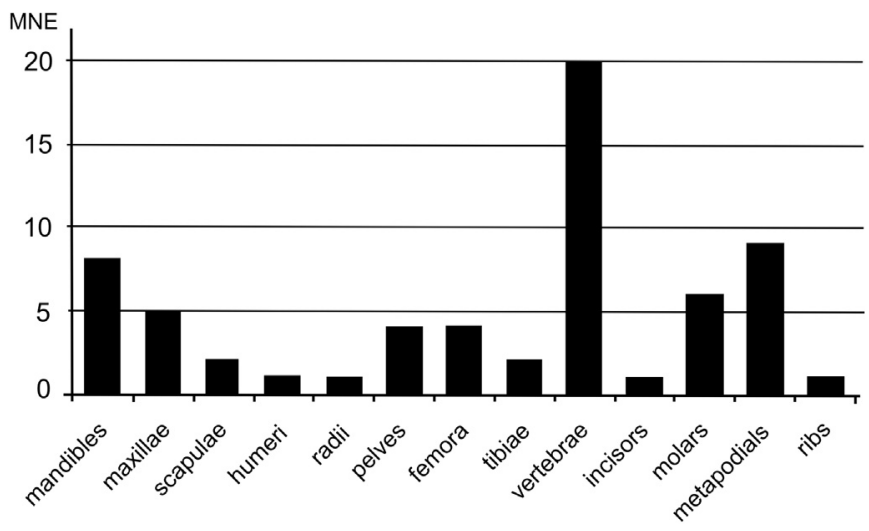

Fig. 3. Minimum number of elements (MNE) identified in the fossil large to medium sized mammals assemblage (except Dasypodidae osteoderms).

corrosion. Most of the specimens (70\%) display evidence of impregnation with manganese oxides, mainly included in Type 3 and Type 4 (sensu Marín Arroyo et al., 2008).

\subsection{Micromammals and other microvertebrates accumulations}

\subsubsection{Taxonomic structure}

This assemblage is dominated by caviomorph rodents including Ctenomys sp. (59.60\%), Microcavia australis (7.10\%) and Galea leucoblephara (5.10\%), followed by cricetid rodents including Reithrodon auritus (15.10\%), Graomys griseoflavus (4.10\%), Akodon dolores (2\%), Eligmodontia typus (2\%) and Calomys cf. C. laucha-C. musculinus (1\%), and the marsupials Thyllamis pallidior (2\%) and Lestodelphis halli (2\%) (Table 2, Fig. $2 \mathrm{~h}-\mathrm{q})$. Scarce fragmentary specimens of other vertebrates were identified (but not included in the taphonomic analysis), belonging to anuran amphibians, squamate reptiles and passerine birds. This assemblage is characterized by a NISP of 831, MNE of 762 (Table 3) and MNI of 99 (Table 2). Juveniles are represented by 27 individuals (Ctenomys sp. $=70.30 \%$;
M. australis $=22.22 \%$; other taxa $=7.48 \%$ ).

\subsubsection{Taphonomic signature}

Specimens were found as discrete irregular accumulations in the bearing level (Fig. $1 \mathrm{~g}$ and $\mathrm{h}$ ), but disarticulated and isolated (sensu Behrensmeyer, 1991). Each accumulation was composed of numerous specimens corresponding to more than one individual and more than one taxon.

All the skeletal elements were represented in this sample (Table 3). The $51.70 \%$ of the specimens correspond to cranial elements (maxillae, mandibles and isolated teeth), while the remaining percentage includes diverse postcranial elements. The anatomical representation indicates a high frequency of mandibles, maxillae, femora and humeri (Table 3).

The average of the relative abundance is $18.38 \%$. The relationship between cranial and postcranial elements (f $+\mathrm{h} /$ $\mathrm{md}+\mathrm{mx}=58.28$ ) shows loss of postcranial bones, and the relationship between proximal and distal elements of the limbs $(t+u$ / $\mathrm{f}+\mathrm{h}=16.46$ ) reflects a high deficit of distal bones.

Incomplete specimens represent $72.97 \%$ of the sample. Complete skulls are not preserved, and the most frequent portions are maxillae and rostra. Complete mandibles are very scarce; instead, mandibles lacking the coronoid processes and/or the condyles are very frequent. Some mandibles (5.66\%) show breakage at the base of the alveolar sockets near the ventral border. Among the postcranial elements, humeri, femora, tibiae, vertebrae and metapodials are preserved complete.

The postcranial elements evaluated for breakage degree (Andrews, 1990) are shown in Table 4 . The $49.09 \%$ of the specimens are complete. The $66 \%$ of the incomplete specimens shows spiral or stepped fractures and $34 \%$ presents smooth transverse fractures or combinations of different types of fractures.

Several specimens show signs of digestive corrosion (Table 5, Fig. 5), mainly light. In $11 \%$ of Ctenomys molars, the enamel surface presents slight pitting. In $10 \%$ of Caviidae molars, digestion is visible because the labial and lingual corners of the teeth are rounded and the protruding angles flattened. In 9\% of Cricetidae molars, matt

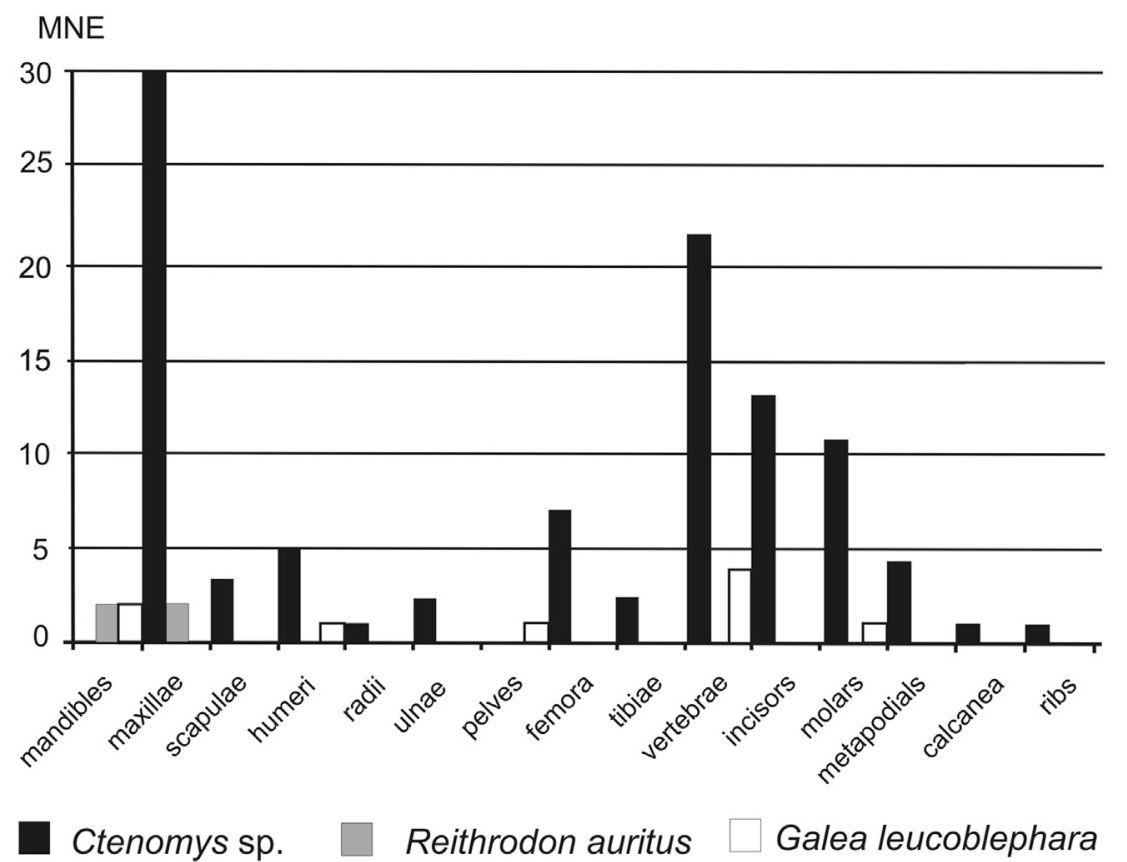

Fig. 4. Minimum number of elements (MNE) obtained in the fossil micromammals associated with burrows assemblage. 
Table 3

Minimum number of elements (MNE) and relative abundance (Rel. Ab.) obtained in the micromammals discrete accumulations, based on a MNI $=99$.

\begin{tabular}{lll}
\hline Elements & MNE & Rel Ab. \\
\hline mandible & 159 & 80.30 \\
maxilla & 131 & 66.16 \\
scapula & 15 & 7.58 \\
humerus & 77 & 38.89 \\
radius & 5 & 2.53 \\
ulna & 8 & 4.04 \\
pelvis & 29 & 14.65 \\
femur & 92 & 46.46 \\
tibia & 20 & 10.10 \\
vertebra & 71 & 1.99 \\
incisor & 57 & 14.39 \\
molar & 42 & 2.65 \\
metapodial & 32 & 0.58 \\
calcaneus & 3 & 1.52 \\
astragalus & 3 & 1.52 \\
Rib & 18 & 0.76 \\
Total & 762 & \\
Average & & 18.38 \\
\hline
\end{tabular}

enamel is visible in lateral view. No molar of these taxa display the dentin affected by digestion.

None of the specimens shows signs of weathering (category 0 ) or abrasion (category 1, sensu Alcalá, 1994). Most of the specimens (90\%) display evidence of impregnation with manganese oxides, mainly included in Type 4 but also in Type 2 and Type 3 (sensu Marín Arroyo et al., 2008).

\section{Discussion}

\subsection{Taphonomic history}

Fluvial dynamic is recorded along the Late Pleistocene and Holocene at the Quehué valley (Calmels et al., 1996), featured by the occurrence of the ephemeral course of the Quehué creek (Mehl and Zárate, 2008). In the rather narrow overbank area of the Quehué creek, the Late Quaternary is recorded by deposits from suspension loads (Unit 1) and from traction fluid flows (Unit 2), that were stabilized by pedogenic processes, one at the beginning of the Holocene $\left(9040 \pm 580{ }^{14} \mathrm{C}\right.$ years BP) and the other at the Late Holocene (1258 $\pm 75{ }^{14} \mathrm{C}$ years $\left.\mathrm{BP}\right)$. After the last period of soil formation, aeolian deposition partially covered the fluvial valley and the surrounding structural plain. An episode of incision cut the Late Pleistocene and Holocene sedimentary sequence and determined the present-day talweg of the Quehué creek, where also Late Miocene deposits crop out (Mehl and Zárate, personal communication).

As mentioned above, field observations (e.g. disposition in the sedimentary sequence) and preservational features suggest different taphonomic histories for the Late Holocene vertebrate specimens recovered from Unit 2 . In this context, three assemblages were identified.
Table 5

Percentages of digestive corrosion in postcranial elements (proximal femora and distal humeri) and teeth (incisors and molars) belonging to the micromammals discrete accumulations.

\begin{tabular}{llllll}
\hline & \% absent & \% light & \% moderate & \% heavy & \% extreme \\
\hline Femur & 50.58 & 33.33 & 12.64 & 3.45 & 0 \\
Humerus & 72.31 & 26.15 & 1.54 & 0 & 0 \\
Molar & 89.58 & 10.42 & 0 & 0 & 0 \\
Incisor & 92.98 & 5.27 & 1.75 & 0 & 0 \\
\hline
\end{tabular}

\subsubsection{Large to medium sized mammals assemblage}

In this assemblage (NISP $=181$ ), specimens from 11 individuals were recovered, which were assigned to xenarthrans, artiodactyls, carnivores and rodents, whose body mass vary approximately between 3 and $90 \mathrm{~kg}$. Dasypodid osteoderms were the dominant skeletal elements (NISP $=106$ ), frequency consistent with their abundance in each carapace, and also vertebrae, the most abundant elements in mammal skeletons, were numerous.

Among the skeletal elements easily transported by water flows (groups I and I-II of Voorhies, 1969) there were pelves, ribs, scapulae, metapodials and vertebrae. Among vertebrae, noteworthily, only four of them were isolated, the rest were, although disarticulated, forming small accumulations that may have been mobilized when they still had connective tissues or most likely underwent little transport and dispersion. Mandibles and maxillae were recorded as well, which are resistant to transport (groups II-III and III of Voorhies, 1969). Although in low frequency, skeletal elements belonging to the different groups proposed by Voorhies are represented in this assemblage, suggesting that the hydrodynamic sorting was not very important. As well, the isolated teeth/isolated vertebrae index (1.5) also suggests a low degree of hydrodynamic sorting. Similar values were reported by different authors for floodplain deposits (see Behrensmeyer, 1975; Badgley, 1986; Tomassini and Montalvo, 2013). These results agree with the low energy interpreted for the environmental context in which the specimens were preserved.

The dominance of disarticulated and isolated specimens indicates that, in most cases, the exposure time was enough for the separation and dispersion of the different bones present in the carcass. The presence of some small accumulations composed by disarticulated but associated specimens, including parts of armadillo carapaces and vertebrae of Mammalia indet., suggests a relatively rapid burial. Muñoz (2015) stated that armadillo carapaces delay the disarticulation of other skeletal elements acting as protective structures. However, in this assemblage there are no other skeletal elements of armadillos apart from three mandibles, which are elements that disarticulate in early stages (Muñoz, 2015); the presence of just portions of carapaces suggests that individuals were already in final stages of disarticulation and anatomical elements removed from the assemblage.

The large-medium sized mammals assemblage constitute an accumulation related with action of surface flows -water (Rogers and Kidwell, 2007). However, complete specimens prevailed, suggesting they were not affected by destructive taphonomic processes. Among incomplete specimens, most of them showed

Table 4

Breakage degree of different limb bones of the micromammals discrete accumulations.

\begin{tabular}{|c|c|c|c|c|c|c|c|c|c|c|}
\hline & \multicolumn{2}{|c|}{ Femur } & \multicolumn{2}{|c|}{ Humerus } & \multicolumn{2}{|l|}{ Tibia } & \multicolumn{2}{|l|}{ Ulna } & \multicolumn{2}{|c|}{ Radius } \\
\hline & MNE & $\%$ & MNE & $\%$ & MNE & $\%$ & MNE & $\%$ & MNE & $\%$ \\
\hline Complete & 38 & 41.30 & 37 & 48.05 & 8 & 40.00 & 0 & 0 & 0 & 0 \\
\hline Proximal & 49 & 53.26 & 12 & 15.58 & 6 & 30.00 & 8 & 100 & 5 & 100 \\
\hline Distal & 5 & 5.44 & 28 & 36.37 & 6 & 30.00 & 0 & 0 & 0 & 0 \\
\hline
\end{tabular}




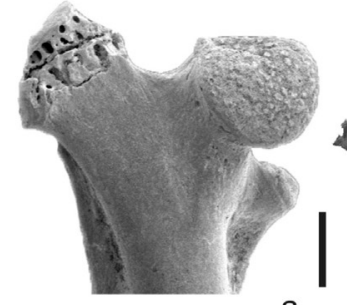

a

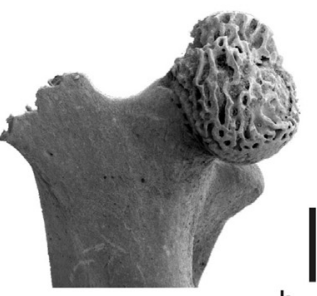

b

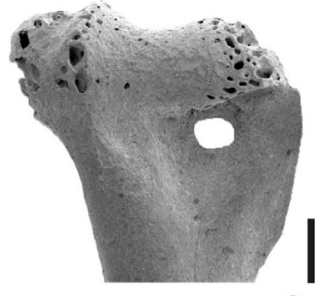

c

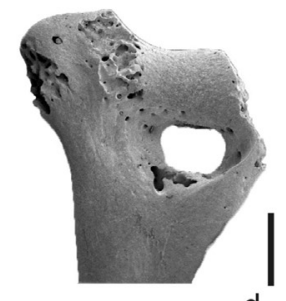

d
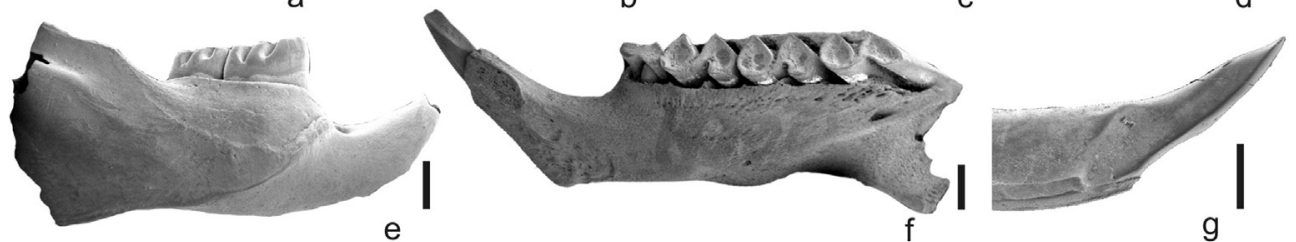

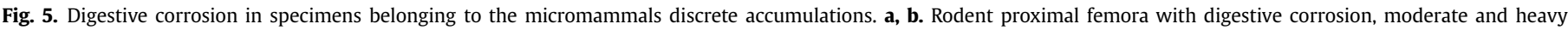

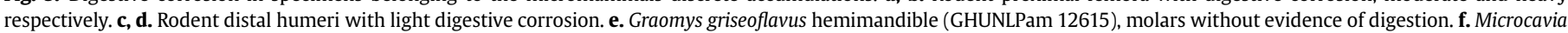
australis hemimandible (juvenile, GHUNLPam 12609), incisor and molars without evidence of digestion. g. Rodent incisor with moderate digestive corrosion.

smooth transverse fractures that may be interpreted as produced during fossil-diagenetic stage, once the bones were already mineralized. On the other hand, fractures related to the biostratinomic stage (stteped and spiral fractures) are scarce; distortion recorded in the palate of Lama sp. (Fig. 2e). could have been originated by the trampling produced by other mammals.

Some specimens showed evidences of weathering (e.g. slight splitting), that indicate exposition to atmospheric agents. The little amount of affected specimens, all of them with low intensities, suggests that exposure time was relatively short.

Specimens from this assemblage did not show signs of abrasion that could be related to water transport. However, the abundance of disarticulated and isolated specimens and the low representativity of skeletal elements for each recorded taxon, accumulated in an environmental context subject to sporadic flooding, suggest that bones may have been mobilized after burial.

\subsubsection{Micromammals associated with burrows}

This assemblage included specimens (NISP $=160$ ) belonging to 25 individuals, recovered inside burrows or associated with them. Three rodent taxa (whose body mass is below $1 \mathrm{~kg}$ ) were recorded, G. leucoblephara, $R$. auritus and Ctenomys sp.; the latter supplied the highest values of MNI and MNE. The anatomical representation showed a high percentage of cranial elements; maxillae and mandibles are preserved in most individuals. The postcranial elements are scarce and the distal limb bones have very low representativity.

All specimens were disarticulated but associated, both those recorded inside the burrows and those associated with them. This suggests that each individual was buried relatively quick.

Incomplete specimens prevailed, as evidence of the action of diverse destructive taphonomic processes. Fractures recorded were produced both on fresh bones (e.g. spiral and stepped) and mineralized remains (e.g. smooth transverse).

The presence of smooth transverse fractures and low values of relative abundance of skeletal elements of each individual may be related to different post-burial destructive processes; among them, the mobilization due to digging rodents (see Bocek, 1986), load generated by the overlying sediments, and the erosion of the bearing levels. Finally, a bias linked to the location of each burrow in relation to the current bed of the creek, may be proposed. Burrowers prefer well drained soils in upland areas; consequently, in areas under seasonal flooding, burrowers were absent (see
Voorhies, 1975). Probably over time, the studied deposits were subject to sporadic flooding, which could have caused the loss of some remains.

The absence of marks related to predation, particularly corrosion by digestive acids, rule out the participation of predators or scavengers in the origin of this assemblage. Also, the specimens had no evidences of weathering, possibly because of the protection of the burrow. The finding of individuals constituted by disarticulated but associated specimens, added to the absence of signs of abrasion, allows inferring that if there was mobilization of bones, this was very scarce.

These results are coincident with previous taphonomic studies performed by Peña (1997) and Tomassini et al. (2017) in Pliocene and Holocene burrows, respectively, of the Pampean Region. These authors indicated that the specimens recovered inside burrows were mostly articulated or associated, with good preservation degree (mostly complete, and without signs of weathering and abrasion); in both cases skull and mandibles were frequent, and in less degree bones of the limbs.

According to the available evidence, some burrows are interpreted to have acted as traps (see Behrensmeyer and Hook, 1992; Tomassini et al., 2017). In this context, it can be interpreted that some individuals could have died inside the burrows, probably trapped during eventual flooding events.

It has been proposed that the burrowing habit might increase the chances for fossilization (Voorhies, 1975). Ctenomys sp., the most frequent taxon of this assemblage, is a fossorial rodent. Their living populations are composed of semi-isolated demes, occupying patches of habitat where soil hardness and particle size provides suitable conditions for burrowing activities (Busch et al., 2000; Mora et al., 2007). In Quehué site, sedimentological features of the bearing level agree with those of the environments in which the species of Ctenomys dig their burrows, and the diameters of the tunnels of the burrows that could be measured coincide with those of modern ones (Antinuchi and Busch, 1992). Galea leucoblephara often utilized the abandoned burrows of larger mammals, such as armadillos (Chaetophractus spp.), plains vizcacha (Lagostomus maximus) and tuco tuco (Ctenomys spp.) (see Rood, 1972). Reithrodon auritus can excavate tunnel systems, but sometimes used burrows dug by Ctenomys (Pardiñas and Galliari, 2001). In this context, it can be proposed that individuals of Ctenomys sp. were the producers of the burrows, whereas the individuals of G. leucoblephara and $R$. auritus would be occasional occupants. 


\subsubsection{Micromammals and other microvertebrate accumulations}

This assemblage (NISP $=831$ ) is composed by 99 individuals of several species of rodents and marsupials (but also other microvertebrates: anurans, reptiles, and birds), included disarticulated and isolated specimens recovered in small discrete accumulations (Fig. $1 \mathrm{~g}$ and $\mathrm{h}$ ). According to the disposition of the specimens in the bearing level, and their taphonomic features, the accumulations were interpreted as disaggregated pellets produced by a predator.

Specimens without digestion evidences prevailed in the sample. Most affected specimens showed a light degree of corrosion. These characteristics coincide with the accumulations of small mammals generated by strigiform birds (Andrews, 1990; Fernández-Jalvo and Andrews, 1992; Fernández et al., 2017). On the basis of the strigiforms inhabiting today in the Quehué valley, the data were compared to those of Tyto alba, Athene cunicularia and Bubo virginianus. Comparison (discriminating by taxon) between these living strigiforms (see Fernández et al., 2017) and the Late Holocene sample, in relation to the modifications produced by digestion, reflected that the latter had a little higher percentages of molars of Cavidae and Ctenomys. In this regard, A. cunicularia and B. virginianus produce accumulations with higher percentages of modifications by digestive corrosion than T. alba (Andrews, 1990; Gómez, 2007; Montalvo and Tejerina, 2009; Montalvo et al., 2015).

All the skeletal elements were represented, but the average of relative abundance was low (18.38\%). For T. alba, Andrews (1990) obtained averages between $27.20 \%$ and $63.20 \%$. For $A$. cunicularia, Gómez (2007) reported an average of $35.45 \%$ and Montalvo and Tejerina (2009) of $55.62 \%$, in both cases based on samples from the Pampean Region. For a sample of $B$. virginianus from Mendoza Province, Montalvo et al. (2015) reported an average of $47.80 \%$. The values of modern samples of strigiforms are higher than those of Quehue site, which is reflected in the curve of anatomical representation (Fig. 6). Samples are coincident in the good representativity of cranial elements (mandibles and maxillae were abundant). Differences in the representation of some skeletal elements and averages could be related to the loss of most fragile bones (scapulae, radii, ulnae) or smallest (autopodial elements, vertebrae, ribs). The evaluated indexes for Quehué site showed a better representation of cranial elements and a higher loss of distal bones with respect to modern samples.

Incomplete specimens prevailed in this assemblage. Percentage of complete limb bones was high (41.10\%), similar to that of B. virginianus (40\%, Montalvo et al., 2015), but lower than those of T. alba (96.60\%, Gómez, 2007) and A. cunicularia (71.40\%, Gómez, 2007; 73.77\%, Montalvo and Tejerina, 2009). An important percentage of specimens showed fractures probably produced before burial (66\%); even so, the post-burial fractures must also be taken into account, because they may have affected complete specimens or may have masked previous fractures.

Based on these evidences, it is proposed that the discrete accumulations of micromammals and other microvertebrates studied herein were produced by the predatory activity of strigiforms. Although the different taphonomic variables do not indicate an owl species in particular, the habits and behaviors of the species that currently inhabit the area can shed light on the accumulator agent. A. cunicularia occurs in open areas, nests and rests in burrows excavated by itself or by mammals such as the plains vizcacha Lagostomus maximus (Marks et al., 1999); this behavior might increase the chances for pellets preservation. The taxonomic structure recorded in the assemblage of Quehué site mostly coincides with A. cunicularia trophic activity known for La Pampa Province (Tommaso et al., 2009; Solaro et al., 2012; see Table 1). Coincidentally, correspondence analysis is consistent to order the assemblage of Quehué site close to those of A. cunicularia (Fig. 7). Unlike most owls (e.g. T. alba and B. virginianus), A. cunicularia is often active during the day, thus usually preys on diurnal rodents such as juveniles of Ctenomys spp., G. leucoblephara and M. australis (Marks et al., 1999); in agreement with these observations, in the sample of Quehué site there were several juvenile individuals (28\%).

Quintana (2015) studied the taphonomic features of bones recovered from disaggregated modern pellets of $T$. alba and stated that post-depositional processes affect them early, but a prolonged period of exposure is required for them to be expressed. No evidence of weathering, trampling, and abrasion were recognized in the assemblage of Quehué site; hence, a rapid burial of pellets can be proposed.

Finally, impregnation by manganese oxides produced modifications in specimens of the three assemblages. In the large to medium sized mammals assemblage a low percentage of specimens was affected (20\%), whereas in the other two assemblages the amount of affected specimens was very high ( $>80 \%$ ). Precipitation

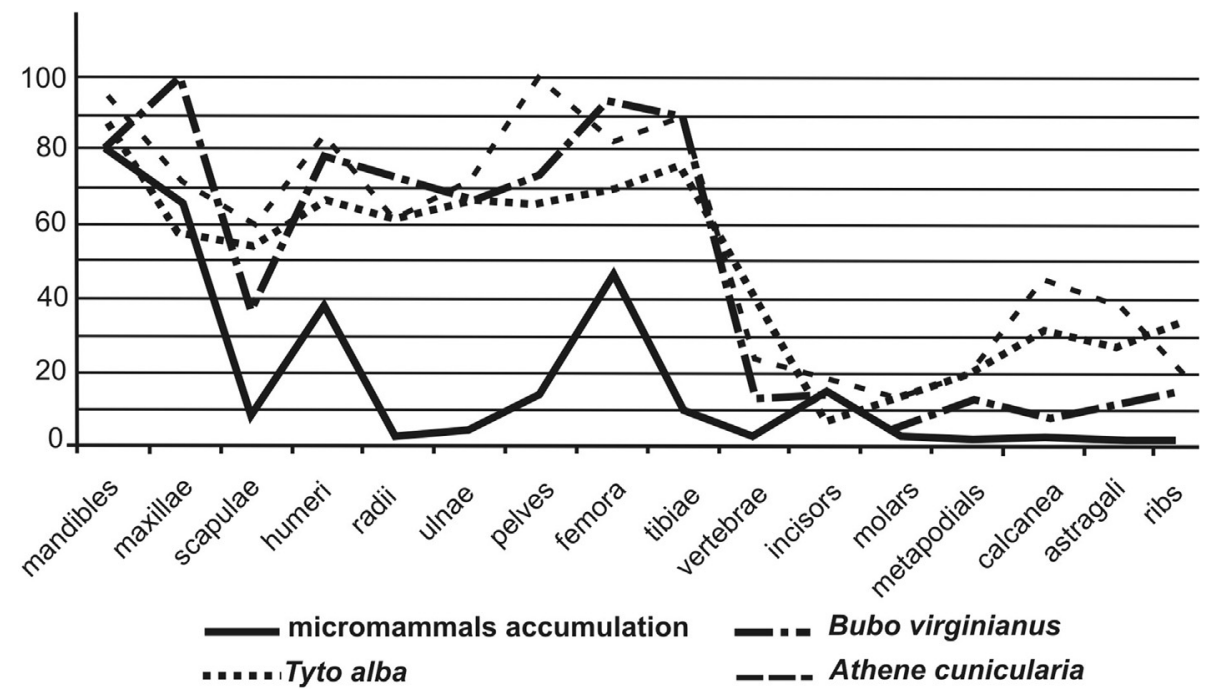

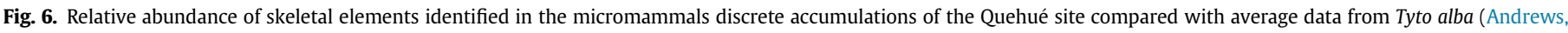
1990), Athene cunicularia (Montalvo and Tejerina, 2009) and Bubo virginianus (Montalvo et al., 2015). 


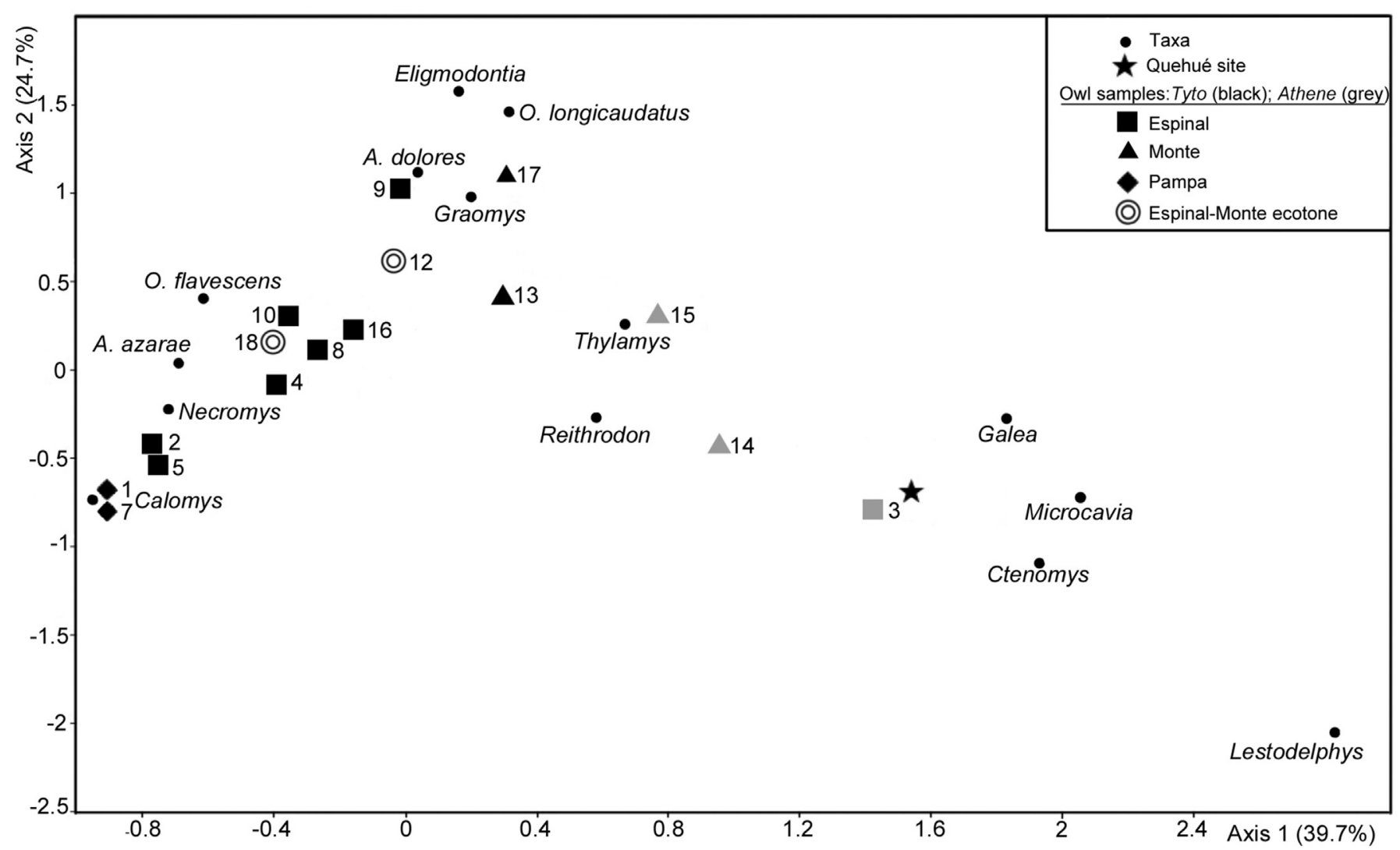

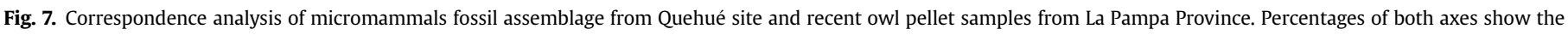
variance. Numbers are those used in Table 1 as ID. Note: Espinal (1 and 11) and Monte (19) owl pellet samples were excluded because of their low values (MNI< 50).

of manganese oxides is one of the main fossil-diagenetic processes by which specimens become impregnated and acquire a dark color (e.g. López-González et al., 2006; Marín Arroyo et al., 2008). The most frequent origin of these impregnations is related to the high concentrations of manganese present in the water that circulates by the fossiliferous levels (Pfretzschner and Tütken, 2011). As occurs in other fossil assemblages of the Pampean Region, the most affected fossils are the smallest ones (Tomassini et al., 2014; Montalvo et al., 2016). It is interpreted that the specimens of the three assemblages were modified by the same post-burial processes.

\subsection{Paleoenvironmental interpretation}

Correspondence analysis based on taxonomic identifications and recent pellets results ordered the modern samples by phytogeographic units (with the exception of the sample of $A$. cunicularia from Curru-Mahuida locality) and by owl species (Fig. 7). In fact, the main factor (axis 1,39.7\% of the variance) shows samples associated with the Pampa and Espinal towards the left, and with the Monte desert towards the middle. The sample of Quehué site is close to those recent pellet samples of $A$. cunicularia from Monte and Espinal, possibly due to the greater proportion of the caviomorph rodents Ctenomys, Galea and Microcavia, and other small mammals typically allied (e.g. G. griseoflavus, A. dolores, E. typus and T. pallidior) but not exclusive of these phytogeographic units (see also Table 1). This is supported by the presence in the bearing level of medium and large mammal taxa (Lama sp., L. gymnocercus, Dolichotis sp., Lagostomus sp., C. villosus, Chaetophractus $\mathrm{cf}$. C. vellerosus and $Z$. pichiy), which currently also inhabit in these two phytogeographic units. In addition, the occurrence of $R$. auritus suggests the development of open, herbaceous steppe environments associated with water bodies. On the other hand, the sample of Quehué site is separated from small mammal samples of the Pampa phytogeographic unit, located in the eastern fringe of La Pampa Province (Fig. 1a), because this latter is mainly composed by the sigmodontine rodents Calomys spp., A. azarae and $O$. flavescens (see also Table 1).

The isolation of $L$. halli, considering both axes of the correspondence analysis, is coherent with the single record in the fossil sample of the Quehue site. The other species found in the sample of Quehué site (including small, medium and large-sized mammals) are currently present in the area (e.g. Redford and Eisenberg, 1992; Siegenthaler et al., 2004; Patton et al., 2015). Nowadays, the vast majority of current localities with presence of $L$. halli (>90\%) corresponds to Patagonian steppe, where cool and dry climatic conditions are dominant (e.g. Formoso et al., 2016; and references therein). The main exceptions correspond to the Monte of the north of Río Negro Province, Mendoza Province and south of La Pampa Province. There are two records of $L$. halli in the last-mentioned province, one in a rocky area with abundant grass cover at Parque Nacional Lihué Calel $\left(37^{\circ} 57^{\prime} \mathrm{S}, 65^{\circ} 33^{\prime} \mathrm{W}\right)$, and the other at Laguna La Amarga $\left(38^{\circ} 12^{\prime} \mathrm{S}, 66^{\circ} 05^{\prime} \mathrm{W}\right) 40 \mathrm{~km}$ south from Parque Nacional Lihué Calel (Birney et al., 1996; Teta et al., 2009). These modern populations of $L$. halli were considered relicts of those that were more widely distributed earlier in the Holocene; thus, they appear to be more vulnerable to becoming extinct (e.g. Formoso et al., 2016). Therefore, the presence of this marsupial in the Quehué site enlarges its known distribution in La Pampa Province ca. $130 \mathrm{~km}$ to the NE, and corroborates its wider geographic extension 
during the Late Holocene.

In surrounding regions (e.g. humid Pampa, Mendoza and Patagonia), there are also several Holocene records of $L$. halli (e.g. Fernández, 2010; Fernández et al., 2016; Tomassini et al., 2017; see also Formoso et al., 2016, and references therein). In addition, in coincidence with the Quehué site, two Late Holocene archaeological sites located in the Monte desert (Agua de La Mula, $35^{\circ} 22^{\prime} \mathrm{S}$, $68^{\circ} 15^{\prime} \mathrm{W}$, Mendoza Province, $1.6-1$ ky BP; Cueva Galpón, $41^{\circ} 09^{\prime} 40^{\prime \prime} \mathrm{S}, 65^{\circ} 47^{\prime} 32^{\prime \prime} \mathrm{W}$, Río Negro Province, $3.3-1.9$ ky BP), recorded similar taxonomic composition of the small mammal assemblages, with the local extinction of L. halli (Fernández, 2010; Fernández et al., 2016).

Possibly the present retraction of this marsupial has combined the effects of the most recent anthropic impact with climatic variations, including the general increase in moisture and temperature in Central Argentina (Viglizzo et al., 1995; Formoso et al., 2016). The impact of recent climatic fluctuations, such as MCA (relatively warmer and wetter) or LIA (relatively colder and drier), would has been expressed as minor variations in the frequencies of some taxa and/or in the expansion/retraction of others (e.g. Fernández, 2010; Fernández et al., 2016). Sedimentary deposits with ages consistent with the regional timing for both climatic episodes were detected in the Quehué valley (Mehl, 2011). The sedimentological and palynological records of Salina Anzoátegui in southeastern La Pampa Province $\left(39^{\circ} 00^{\prime} \mathrm{S}, 63^{\circ} 46^{\prime} \mathrm{W}\right)$ allowed to recognized the Espinal phytogeographic unit, with minor variations from the middle Holocene until recent times, suggesting persistent arid to semi-arid conditions (e.g. Schäbitz, 1994). In this context, the anthropic impact and the more mesic conditions could have played a major role in the retraction of $L$. halli in the dry Pampa. The progressive development of agricultural and livestock activities in the Pampean and Patagonian regions, mainly during the last 200 years, has yielded an overexploitation of pastures, an increase of open areas with bare soil and bushes (e.g. Perelman et al., 1997).

\section{Conclusions}

Numerous vertebrate remains (mainly mammals) were recovered from Late Holocene fluvial deposits of the Quehué valley, La Pampa Province. The disposition of the specimens in the bearing level and the taphonomical features allowed differentiation of three assemblages, with different biostratinomic histories.

Large to medium sized mammals, is an attritional assemblage formed by specimens mobilized probably during flooding events. The assemblage of micromammals associated with burrows, includes well preserved specimens of individuals that would have died inside the burrows (produced by Ctenomys sp.) or near them. Micromammals and other microvertebrates discrete accumulations, the most numerous in amount of specimens and individuals, were interpreted as produced by the disaggregation of pellets generated by a strigiform, possibly A. cunicularia. These two latter involve very short intervals, endorsing the idea that the taxa included were coetaneous. According to the results obtained, burial was very rapid in the three assemblages; even so, it may be suggested that the micromammals associated with burrows were the ones that suffered the most rapid burial, following by the micromammals of the discrete accumulation and finally the large to medium sized mammals.

The paleoenvironmental analysis based on the small mammals displayed semi-arid conditions associated with a mosaic of open shrub steppe, grasslands and xerophytic forests of Espinal, similar than today at the Quehué valley. This hypothesis is also supported by the presence of medium and large fossil mammals, and by other studies (e.g. sedimentology, palynology). However, the presence of L. halli in the Quehué site during the Late Holocene ( 1.2 ky BP), suggests a more heterogeneous environment and perhaps relative colder and drier than current times, which are featured by more mesic conditions and anthropic activities mainly agriculture and livestock during the last centuries.

\section{Acknowledgements}

To S. Tiranti and M. Ramírez Chico for taxonomic determination of some specimens, and to C. Deschamps for the English translation. We thank F. Vega and three anonymous reviewers for their useful comments that improved the manuscript. This work has been funded by Project 05G of the Facultad de Ciencias Exactas y Naturales, UNLPam.

\section{References}

Alcalá, L., 1994. Macromamíferos neógenos de la fosa de Alfambra-Teruel. Instituto de Estudios Turolenses y Museo Nacional de Ciencias Naturales, Teruel, 554 pp.

Andrews, P., 1990. Owls, Caves and Fossils. Predation, Preservation, and Accumulation of Small Mammal Bones in Caves, with the Analysis of the Pleistocene Cave Faunas from Westbury-sub-mendip, Somerset. UK. Natural History Museum Publications, London, 231 pp.

Antinuchi, C.D., Busch, C., 1992. Burrow structure in the subterranean rodent Ctenomys talarum. Z. Saugetierkd. 57, 163-168.

Badgley, C., 1986. Counting individuals in mammalian fossil assemblages from fluvial environments. Palaios 1, 328-338.

Bargo, M.S., Montalvo, C.I., Chiesa, J.O., Forasiepi, A.M., Cerdeño, E., Lucero, N.P. Martinelli, A.G., 2010. El registro de mamíferos del Pleistoceno tardío-Holoceno temprano del centro-oeste de Argentina. In: Zárate, M.A., Gil, A., Neme, G. (Eds.), Condiciones paleoambientales y ocupaciones humanas durante la transición Pleistoceno-Holoceno y Holoceno de Mendoza. Sociedad Argentina de Antropología, Buenos Aires, pp. 213-218.

Behrensmeyer, A.K., 1975. The taphonomy and paleoecology of Plio-Pleistocene vertebrate assemblages of Lake Rudolf, Kenya. Bull. Mus. Comp. Zoology 146 473-578.

Behrensmeyer, A.K., 1991. Terrestrial vertebrate accumulations. In: Allison, P.A. Briggs, D.E.G. (Eds.), Taphonomy: Releasing the Data Locked in the Fossil Record. Plenum Press, New York, pp. 291-335.

Behrensmeyer, A.K., Dechant Boaz, E., 1980. The recent bones of Amboseli Park Kenya, in relation to East African paleoecology. In: Behrensmeyer, A.K., Hill, A.P. (Eds.), Fossils in the Making. Vertebrate Taphonomy and Paleoecology. University of Chicago Press, Chicago, pp. 72-92.

Behrensmeyer, A.K., Hook, R.W., 1992. Paleoenvironmental contexts and taphonomic modes in the terrestrial fossil record. In: Behrensmeyer, A.K. Damuth, J.D., Di Michele, W.A., Potts, R., Sues, H.D., Wing, S.L. (Eds.), Terrestrial Ecosystems through Time. University of Chicago Press, Chicago, pp. 15-136.

Bidau, C.J., 2015. Family Ctenomyidae. In: Patton, J.L., Pardiñas, U.F.J., Délía, G. (Eds.), Mammals of South America, vol. 2. Rodents. The University of Chicago Press, London and Chicago, pp. 818-876.

Birney, E.C., Monjeau, J.A., Phillips, C.J., Sikes, R.S., Kim, I., 1996. Lestodelphys halli: new information on a poorly known Argentine marsupial. Mastozoología Neotropical 3, 171-181.

Bocek, B., 1986. Rodent ecology and burrowing behavior: predicted effects on archaeological site formation. Am. Antiq. 51, 589-603.

Burgos, J.J., 1968. Los climas de la provincia de Buenos Aires en relación con la vegetación natural y el suelo. In: Cabrera, A.L. (Ed.), Flora de la provincia de Buenos Aires. Colección Científica Instituto Nacional de Tecnología Agropecuaria, Buenos Aires, pp. 33-99.

Busch, C., Antinuchi, C.D., Del Valle, J.C., Kittlein, M.J., Malizia, A.I., Vasallo, A.I., Zenuto, R.R., 2000. Population ecology of subterranean rodents. In: Lacey, E.A., Patton, J.L., Cameron, G.N. (Eds.), Life Underground: the Biology of Subterranean Rodents. University of Chicago Press, Chicago and London, pp. 183-226.

Cabrera, A.L., 1976. Regiones fitogeográficas argentinas. Encicl. Argent. Agric. Jard. 2, $1-85$.

Calmels, A.P., Visconti, G., Carballo, O., Sbrocco, J., 1996. Los sedimentos del Pleistoceno tardío-Holoceno encauzados en el Valle de Quehué, provincia de La Pampa. Reunión Argentina de Sedimentología. Libro resúmenes 135-140.

Cenizo, M.M., De los Reyes, L.M., 2008. Primeros registros de Tyto alba (Scopoli, 1769) (Strigiformes, Aves) en el Pleistoceno medio-tardío de la provincia de Buenos Aires (Argentina) y sus implicancias tafonómicas. Rev. del Mus. Argent. Ciencias Nat. 10, 199-209.

Cione, A.L., Tonni, E.P., 2005. Bioestratigrafía basada en mamíferos del Cenozoico superior de la provincia de Buenos Aires, Argentina. In: de Barrio, R.E. Etcheverry, R.O., Caballé, M.F., Llambías, E. (Eds.), Geología y Recursos Minerales de la Provincia de Buenos Aires. XVI Congreso Geológico Argentino, pp. 183-200. La Plata.

Cione, A.L., Gasparini, G.M., Soibelzon, E., Soibelzon, L.H., Tonni, E.P., 2015. The Great American Biotic Interchange: a South American Perspective. Springer, New York and London, 97 pp.

De Santis, L.J.M., Montalvo, C.I., Justo, E.R., 1983. Mamíferos integrantes de la dieta 
de Tyto alba (Aves: Strigiformes, Tytonidae) en la provincia de La Pampa, Argentina. Hist. Nat. 3, 187-188.

Fernández, F.J., 2010. Paleozoogeography of the wine mouse (Akodon oenos) and late Holocene paleoenvironments in south-central of Mendoza, Argentina. Ethnobiol. Lett. 1, 52-57. http://dx.doi.org/10.14237/ebl.1.2010.62.

Fernández, F.J., Montalvo, C.I., Fernández-Jalvo, Y., Andrews, P., López, J.M., 2017. A re-evaluation of the taphonomic methodology for the study of small mammal fossil assemblages of South America. Quat. Sci. Rev. 155, 37-49. http:// dx.doi.org/10.1016/j.quascirev.2016.11.005.

Fernández, F.J., Teta, P., Mange, E., Prates, L., González Venanzi, L., Pardiñas, U.F.J., 2016. Micromamíferos del sitio arqueológico Cueva Galpón (Río Negro, Argentina): aspectos tafonómicos y reconstrucción paleoambiental para el Holoceno tardío en Norpatagonia oriental. Rev. Arqueol. 22, 105-124.

Fernández-Jalvo, Y., Andrews, P., 1992. Small mammal taphonomy of Gran Dolina, Atapuerca (Burgos), Spain. J. Archaeol. Sci. 19, 407-428.

Formoso, A.E., Martin, G.M., Teta, P., Carbajo, A.E., Udrizar Sauthier, D.E. Pardiñas, U.F.J., 2016. Regional extinctions and Quaternary shifts in the geographic range of Lestodelphys halli, the southernmost living marsupial: clues for its conservation. PLoS One 10, e0132130. http://dx.doi.org/10.1371/ journal.pone.0132130.

Fracassi, N.G., Pereira, J., Teta, P., 2004. Efectos de la sequía sobre el comportamiento dietario de Tyto alba en el Parque Nacional Lihué Calel, La Pampa, Argentina, p. 30. Primer Simposio Argentino sobre Investigación y Conservación de Rapaces, Libro de resúmenes.

Gómez, G., 2007. Predators categorization based on taphonomic analysis of micromammals bones: a comparison to proposed models. In: Gutierrez, M.A. Miotti, L., Barrientos, G., Mengoni Goñalons, G., Salemme, M. (Eds.), Taphonomy and Zooarchaeology in Argentina. British Archaeological Report, pp. 89-103. S1601.

López-González, F., Grandal-d'Anglade, A., Vidal-Romaní, J., 2006. Deciphering bone depositional sequences in caves through the study of manganese coatings. J. Archaeol. Sci. 20,1-11. http://dx.doi.org/10.1016/j.jas.2005.10.006.

Marín Arroyo, A.B., Landete Ruiz, M.D., Vidal Bernabeu, G., Seva Román, R., González Morales, M.R., Straus, L.G., 2008. Archaeological implications of human-derived manganese coatings: a study of blackened bones in El Mirón Cave, Cantabrian Spain. J. Archaeol. Sci. 35, 801-813. http://dx.doi.org/10.1016/j.jas.2007.06.007.

Martin, P.S., Steadman, D.W., 1999. Prehistoric extinctions on islands and continents. In: MacPhee, R.D.E. (Ed.), Extinctions in Near Time: Causes, Contexts and Consequences. Kluwer/Plenum, New York, pp. 17-56.

Marks, J.S., Cannings, R.J., Mikkola, H., 1999. Family Strigidae (typical owls). In: del Hoyo, J., Elliott, A., Sargatal, J. (Eds.), Handbook of the Birds of the World, vol. 5. Lynx Ediciones, Barcelona, pp. 76-242. Barn-owls to Hummingbirds.

Marshall, L., 1989. Bone modification and "The laws of burial". In: Bonnichsen, R. Sorg, M. (Eds.), Bone Modification. Institute for Quaternary Studies, University of Maine, Orono, pp. 7-24.

Massoia, E., Vetrano, A.S., 1988. Análisis de regurgitados de Tyto alba de Alta Italia, Departamento Realicó. Provincia de La Pampa. APRONA 3, 4-10.

Mehl, A.E., 2011. Sucesiones aluviales del Pleistoceno tardío-Holoceno, Valle de Uco (provincia de Mendoza): inferencias paleoambientales y paleoclimáticas. Unpublished Ph.D. Thesis. Universidad Nacional de La Plata, 355 pp. [In Argentina].

Mehl, A.E. Zárate, M.A. 2008. Sucesiones aluviales del Pleistoceno tardío-Holoceno del valle de Quehué. XII Reunión Argentina de Sedimentología, La Pampa, Argentina, p. 115. Libro de resúmenes.

Montalvo, C.I., 2004. Paleobiología de la asociación faunística de Caleufú (La Pampa Formación Cerro Azul, Mioceno superior-Plioceno inferior) a través de análisis tafonómicos. Unpublished Ph.D. Thesis. Universidad Nacional de, La Plata, 25 pp. [In Argentina].

Montalvo, C.I., Tejerina, P., 2009. Análisis tafonómico de los huesos de anfibios y roedores depredados por Athene cunicularia (Strigiformes, Strigidae) en La Pampa, Argentina. In: Berón, M., Luna, L., Bonomo, M., Montalvo, C.I., Aranda, C., Carrera Aizpitarte, M. (Eds.), Mamül Mapu: pasado y presente desde la arqueología pampeana. Ediciones Libros del Espinillo, vol. 1, pp. 323-334. La Pampa, Tomo.

Montalvo, C.I., Justo, E.R., De Santis, L., 1985. Alimentación de Tyto alba (Strigi formes, Tytonidae) en la Provincia de La Pampa. Neotrópica 30, 250-252.

Montalvo, C.I., Mehl, A.E., Zárate, M.A., 2007. Mamíferos del Pleistoceno tardíoHoloceno en el Valle de Quehué. VI Jornadas Geológicas y Geofísicas Bonaerenses, La Pampa, Argentina, p. 60. Libro de resúmenes.

Montalvo, C.I., Tomassini, R.L., Visconti, G., Tiranti, S., 2012. Análisis tafonómico de micromamíferos del Pleistoceno Superior del Quequén Salado, provincia de Buenos Aires, Argentina. Rev. Bras. Paleontol. 15, 345-358. DOI: 104072 rbp.2012.3.10.

Montalvo, C.I., Fernández, F.J., Tallade, P.O., 2015. The role of Bubo virginianus magellanicus as rodent bone accumulator in archaeological sites. A case study for the Atuel River (Mendoza, Argentina). Int. J. Osteoarchaeol. 26, 974-986. http://dx.doi.org/10.1002/oa.2509.

Montalvo, C.I., Tomassini, R.L., Sostillo, R., 2016. Leftover prey remains: a new taphonomic mode from the late Miocene (Cerro Azul Formation) in central Argentina. Lethaia 49, 219-230. http://dx.doi.org/10.1111/let.12140.

Mora, M.S., Lessa, E.P., Cutrera, A.P., Kittlein, M.J., Vassallo, A.I., 2007. Phylogeographical structure in the subterranean tuco-tuco Ctenomys talarum (Rodentia: Ctenomyidae): contrasting the demographic consequences of regional and habitat-specific histories. Mol. Ecol. 16, 3453-3465. http://dx.doi.org/10.1111/ j.1365-294X.2007.03398.x.

Muñoz, A.S., 2015. Observaciones tafonómicas naturalistas sobre restos de armadillos (Dasypodidae) en Patagonia meridional. Archaeofauna 24, 239-251.

Pardiñas, U.F.J., 1999. Los roedores muroideos del Pleistoceno Tardío-Holoceno en la Región Pampeana (sector este) y Patagonia (República Argentina): aspectos taxonómicos, importancia bioestratigráfica y significación paleoambiental. Unpublished Ph.D. Thesis. Universidad Nacional de La Plata, 283 pp. [In Argentina].

Pardiñas, U.F.J., 2001. Condiciones áridas durante el Holoceno Temprano en el sudoeste de la provincia de Buenos Aires (Argentina): vertebrados y tafonomía. Ameghiniana 38, 227-236.

Pardiñas, U.F.J., 2004. Roedores sigmodontinos (Mammalia: Rodentia: Cricetidae) y otros micromamíferos como indicadores de ambientes hacia el Ensenadense cuspidal en el sudeste de la provincia de Buenos Aires (Argentina). Ameghiniana 41, 437-450.

Pardiñas, U.F.J., Galliari, C.A., 2001. Reithrodon auritus. Mamm. Species 664, 1-8.

Patton, J.L., Pardiñas, U.F.J., Délía, G., 2015. Mammals of South America, vol. 2. Rodents. The University of Chicago Press, London and Chicago, 1336 pp.

Peña, M.I., 1997. Tafonomía de restos óseos y condiciones ambientales del Plioceno Tardío, Playa San Carlos (Pdo. de Gral. Pueyrredón). Unpublished MSc. Thesis. Universidad Nacional de, Mar del Plata, 37 pp. [In Argentina].

Perelman, S.B., León, R.J.C., Bussacca, J.P., 1997. Floristic changes related to grazing intensity in a Patagonian shrub steppe. Ecography 20, 400-406.

Pfretzschner, H.U., Tütken, T., 2011. Rolling bones Taphonomy of Jurassic dinosaur bones inferred from diagenetic microcracks and mineral infillings. Palaeogeogr. Palaeoclimatol. Palaeoecol. 310, 117-123. http://dx.doi.org/10.1016/ j.palaeo.2011.01.026.

Quintana, C.A., 2015. Tafonomía de contenidos dispersos de egagrópilas de Tyto alba en un ambiente serrano. Hist. Nat. 5, 29-47.

Redford, K.H., Eisenberg, J.F., 1992. The Southern Cone. Mammals of the Neotropics, vol. 2. University of Chicago Press, Chicago, 460 pp.

Rogers, R.R., Kidwell, S.M., 2007. A conceptual framework for the genesis and analyses of vertebrate skeletal concentrations. In: Rogers, R.R., Eberth, D.A. Fiorillo, A.R. (Eds.), Bonebeds: Genesis, Analysis, and Paleobiological Significance. University of Chicago, Chicago, pp. 1-63.

Rood, J.P., 1972. Ecological and behavioral comparisons of three genera of Argentine cavies. Anim. Behav. Monogr. 5, 1-83.

Schäbitz, F., 1994. Holocene climatic variations in northern Patagonia, Argentina. Palaeogeogr. Palaeoclimatol. Palaeoecol. 109, 287-294.

Siegenthaler, G.B., Tiranti, S.I., Fiorucci, E.A., 2004. Relevamiento de los vertebrados de la provincia de La Pampa, Primera Edición. Gobierno de La Pampa, Santa Rosa. https://recursosnaturales.lapampa.edu.ar/rel_fr.html.

Solaro, C., Santillán, M.A., Costán, A.S., Reyes, M.M., 2012. Ecología trófica de Athene cunicularia y Tyto alba en el cerro Curru-Mahuida, ecotono Monte-Espinal, La Pampa, Argentina. El Hornero 27, 177-182.

Teta, P., Pereira, J.A., Fracassi, N.G., Bisceglia, S.B., Heinonen Fortabat, S., 2009. Micromamíferos (Didelphimorphia y Rodentia) del Parque Nacional Lihué Calel, La Pampa, Argentina. Mastozoología Neotropical 16, 183-198.

Tiranti, S.I., 1988. Análisis de regurgitados de Tyto alba en la provincia de La Pampa. Asociación para la Protección de la Naturaleza. Bol. Científico 11, 8-12.

Tiranti, S.I., 1992. Barn owl prey in southern La Pampa, Argentina. J. Raptor Res. 26, 89-92.

Tiranti, S.I., 1994. Mammal prey of the barn owl (Tyto alba) in Parque Luro Reserve, La Pampa, Argentina. Hystrix 5, 47-52.

Tommaso, D.C., Callicó Fortunato, R.G., Teta, P., Pereira, J.A., 2009. Dieta de la lechucita vizcachera (Athene cunicularia) en dos áreas con diferente uso de la tierra en el centro-sur de la provincia de La Pampa, Argentina. El Hornero 24, 87-93.

Tomassini, R.L., Montalvo, C.I., 2013. Taphonomic modes on fluvial deposits of the Monte Hermoso Formation (early Pliocene), Buenos Aires Province, Argentina. Palaeogeogr. Palaeoclimatol. Palaeoecol. 369, 282-294. http://dx.doi.org/ 10.1016/j.palaeo.2012.10.035

Tomassini, R.L., Montalvo, C.I., Beilinson, E., Deschamps, C.M., Garrone, M.C., Gasparini, G.M., Zárate, M.A., Rabassa, J., Ruella, A., Tonni, E.P., 2017. Microvertebrates preserved in mammal burrows from the Holocene of the Argentine Pampas: a taphonomic and paleoecological approach. Hist. Biol. 29, 63-75. http://dx.doi.org/10.1080/08912963.2015.1124873.

Tomassini, R.L., Montalvo, C.I., Visconti, G., Manera, T., 2014. Mineralogy, geochemistry and paleohistology of Pliocene mammals from the Monte Hermoso Formation (Argentina). Paedotherium bonaerense (Notoungulata, Hegetotheriidae) as case study. Ameghiniana 51, 385-395. http://dx.doi.org/10.5710/ AMEGH.01.07.2014.2737.

Viglizzo, E.F., Roberto, Z.E., Filippin, M.C., Pordomingo, A.J., 1995. Climate variability and agroecological change in the Central Pampas of Argentina. Agric. Ecosyst. Environ. 55, 7-16.

Voorhies, M.R., 1969. Taphonomy and Population Dynamics of an Early Pliocene Vertebrate Fauna. Contributions to Geology, vol. 1. University of Wyoming, Knox County, Nebraska, pp. 1-69. Special Papers.

Voorhies, M.R., 1975. Vertebrate burrows. In: Frey, R.W. (Ed.), The Study of Trace Fossils. Springer, New York, pp. 325-350. 